\title{
Os modelos da causalidade circular ou dos sistemas feedback na compreensão do vivo ${ }^{\star}$
}

\author{
Hugo Leonardo Rodrigues Soares $\star \star$ \\ Eduardo Henrique Passos Pereira ${ }^{\star \star}$
}

As ciências cognitivas delimitam um campo de investigação que tem como objeto o conhecimento humano e dos diferentes sistemas inteligentes. A capacidade do homem em se tornar sujeito consciente do mundo que o rodeia é um tema privilegiado das ciências cognitivas. Assim destacamos como ciências cognitivas as neurociências, a psicologia cognitiva, a antropologia, a neurolínguistica, a filosofia e a inteligência artificial. Entender o processo do conhecer não delimita um campo homogêneo. Necessitamos lançar mão das áreas biológicas, humanas e exatas para que tenhamos uma apreensão da complexidade do conhecimento humano. Os seres vivos são sistemas moleculares que existem como organismos na contínua produção de si mesmos. O conceito de autopoiese proposto pelos biólogos Humberto Maturana e Francisco Varela conota isso. A teoria da autopoiese se insere no campo das ciências cognitivas, discutindo o tema da cognição a partir da tese da identidade entre viver, fazer e conhecer. Todo ser vivo é um sistema autopoiético já que constitui a si e a seu mundo no ato cognitivo. Como sistemas autopoíeticos os seres vivos existem somente na produção de si mesmos, sendo sistemas fechados na sua dinâmica de estados. Como organismos, os seres vivos existem em interações em um meio que surge com eles no seu fazer e não préexiste ao seu viver. A pesquisa objetivou fazer um levantamento bibliográfico no campo da ciência cognitiva a fim de discutir o impacto causado pelo modelo proposto por Norbert Wiener no campo da Biologia. Estudamos o conceito de sistema feedback e tal como ele é enfatizado pela segunda cibernética. Focalizamos a teoria da autopoiese proposta por Humberto Maturana e Francisco Varela, neurofisiólogos da Universidade do Chile e do CREA (Paris). A medotologia utilizada foi o levantamento bibliográfico e a participação em seminários e discussões no Grupo de Pesquisa Cognição e Subjetividade da UFF, além de eventos e outros encontros científicos cuja convergência seja a Cognição Humana. Na década de 1970, surge na Universidade do Chile uma nova versão para a Biologia do Conhecimento. São os trabalhos de Humberto Maturana e Francisco Varela que,

* Monografia apresentada como conclusão de Pesquisa em Iniciação Científica na Jornada Científica do Curso de Medicina - Agosto de 2004 - Faculdade de Medicina

$\star \star$ Monitor da Disciplina de Psiquiatria Infantil e Desenvolvimento Infantil oferecida no curso de Medicina da UFF.E-mail: hlsoares@insau.medicina.uff.br

$\star \star \star$ Professor Adjunto do Departamento de Psicologia, orientador do projeto. Endereço: UFF ICHF - Departamento de Psicologia - Bloco O, sala 310 - Campus do Gragoatá, São Domingos, Niterói/RJ, CEP 24210-3501 E-mail: e.passos@ superig.com.br 
no interior do campo da ciência cognitiva, definem o ato cognitivo como ato de criação e não como representação da realidade. A questão que se coloca para estes autores é a definição da vida: o vivo é um sistema autopoiético , isto é, sistema capaz de produzir as suas condições de produção. A teoria da autopoiese de Humberto Maturana postula que o acoplamento estrutural é a interação entre células e células, e as células e o meio. Acoplamento estrutural é a interação da célula (unidade autopoiética) com outras unidades autopoiéticas e destas com o meio que as rodeia. A noção de auto-organização assume destaque nas formulações de Maturana e Varela, a ponto de podermos identificar aí um terceiro modelo de análise do fenômeno cognitivo. Coloca-se no centro das preocupações a dimensão temporal, genética e criativa das estruturas do conhecimento. E, se a cognição é o que emerge de uma rede de conexões, se ela resulta da atividade de auto-organização de um sistema fortemente cooperativo (tal como as redes linfocitárias ou redes neurais), é enfatizada a dimensão ontogenética da cognição. 